\title{
SOME SPECIES OF ADIANTUM FROM THE SHIVAPURI NATIONAL PARK, CENTRAL NEPAL
}

\author{
S. Singh ${ }^{1}$ and M. Siwakoti ${ }^{2}$
}

\section{ABSTRACT}

Four species of ferns belonging to genus Adiantum and family Adiantaceae were collected from Shivapuri National Park (ShNP). These were Adiantum capillus-veneris L., Adiantum caudatum L., Adiantum philippense L., and Adiantum raddianum C. Presl. Among these, Adiantum raddianum is reported for the first time from Central Nepal.

Key Words: ferns, Adiantaceae, Kathmandu

\section{INTRODUCTION}

Ferns are found in all climatic zones of Nepal except high Himalayan zones. The protected areas including the Shivapuri National Park (ShNP) are some of the major habitats for their occurrence of fern species. ShNP is the closest park from the capital city Kathmandu, which harbors a large number of fern species. The most of the fern species are herbaceous; they are shade and moisture loving plants. The distribution of the species are greatly affected by the climatic factors from east to west of the country. There is general decrease both in species diversity and population density from east to west region of the country. The altitude of ShNP ranges $1630 \mathrm{~m}$ to $2730 \mathrm{~m}$ and experiences subtropical to lower temperate types of climate. The common vegetation is following:

In lower belt (up to $1900 \mathrm{~m}$ ) Schima-Castanopsis forests were found, the dominant trees were Schima wallichii, Castanopsis indica, Castanopsis tribuloides, Alnus nepalensis, Eurya acuminata, Prunus cerasoides, other trees associated with them were Choerospondias axillaris, Pyrus pashia, Betula alnoides, Myrica esculenta, Myrsine capitellata, Berberis asciatica. Alnus nepalensis was found in moist shady area. Pine forests comprising Pinus roxburghii at lower belt and Pinus wallichiana in upper belt were found in open drier areas. The other trees associate tree species were Eurya acuminata, Schima wallichii, Myrica esculenta, Pyrus pashia, Eriobotrya dubia, Albizia julibrissin, etc.

In the middle belt (2000 to $2300 \mathrm{~m}$ ) Mixed Oak forests were found. The dominant trees were Quercus lanata, Rhododendron arboreum, Cyclobalanopsis glauca (Quercus glauca). The associated tree species were Eurya acuminata, Lyonia ovalifolia, Myrsine semiserrata, Quercus semecarpifolia, Michelia champaca, Rhus succedanea. Cyclobalanopsis glauca were dominant in steep and moist shady places.

In the upper belt (2300 to $2732 \mathrm{~m}$ ) Oak forests were found. The dominant trees in this belt were Quercus semecarpifolia, Quercus lamellosa, Rhododendron arboreum. The other trees associated with them were Pieris formosa, Ilex excelsa, Viburnum nervosum, Lindera pulcherima.

\section{MATERIALS AND METHODS}

The Shivapuri National Park is located between 27 ${ }^{\circ} 45^{\prime}$ and $27^{\circ} 52^{\prime}$ latitude and $85^{\circ} 15^{\prime}$ and 
$85^{\circ} 30^{\prime}$ longitude covering an area of $144 \mathrm{~km}^{2}$ of Kathmandu, Nuwakot and Sindhupalchok districts of Central Development region. The park stretches about $20-40 \mathrm{~km}$ from east to west and about 8-10 km from north to south. The elevation of the park ranges from $1360 \mathrm{~m}$ to 2,732 $\mathrm{m}$ at Shivapuri peak. However most of the park lies between $1600 \mathrm{~m}$ to $2500 \mathrm{~m}$ above the sea level (Figure 1).

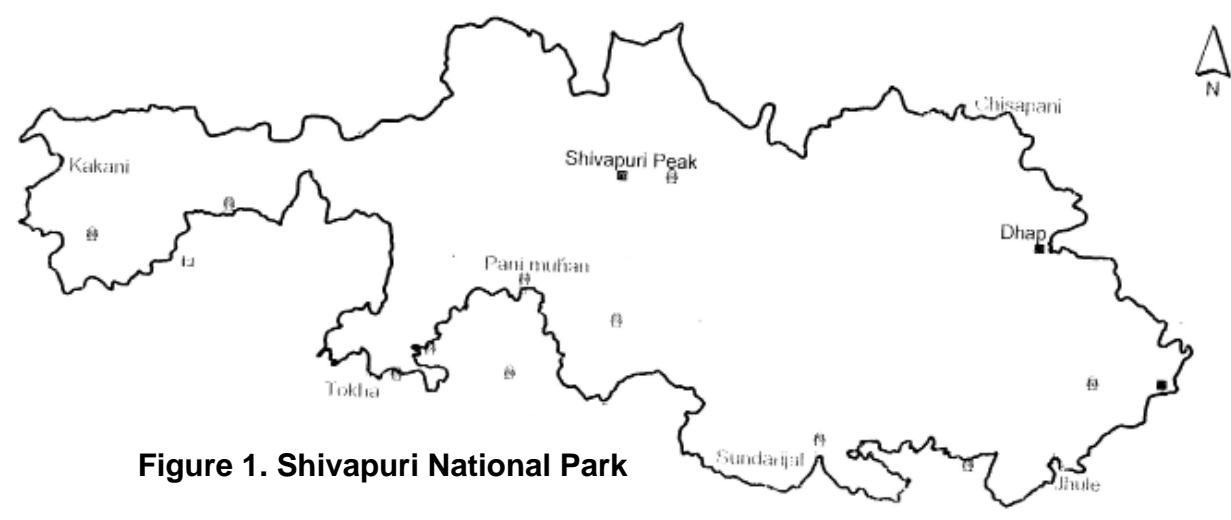

Scale $=1: 100000$

Source: Head quarter of ShNP, Panimuhan (2004)

Fern specimens were collected from Sundarijal and Kakani areas of ShNP at the sorial stage during the month of July 2008. During collection a field note was prepared recording date of collection, locality, altitude, specimen number, occurrence, habitat, longitude and latitude of the area using GPS. Generally 3-4 (at least 2) specimens were collected from the field. Two to three sets of herbarium specimens were prepared. Identification of specimens was made with the help of literature (Beddome 1883, Clarke 1880, Hope 1899-1904, Fraser-jenkins 2008, Gurung 1991, Iwatsuki 1975, 1988, Malla et al. 1986). The voucher specimen has been deposited at Tribhuvan University Central Herbarium (TUCH), Kirtipur, Kathmandu.

\section{RESULTS AND DISCUSSION}

\section{Adiantum capillus-veneris $\mathrm{L}$.}

Local vernacular name: Pakhale uneu

Fructification: June-July

Specimen Examined: Nuwakot, Kakani, 2225 m, July 15, 2008, S. Singh 454 (TUCH). Terrestrial on the stone crevices, walls and mossy, rocky slopes of the shady and dry places, common.

Uses: A paste of the plant is applied to the forehead to relieve headache, and to the chest to relieve chest pain.

Distribution: Nepal (WCE, 100-2300 m), widely distributed in the tropical to temperate regions of the world including W. Britain and S. USA. 


\section{Adiantum caudatum L.}

Local vernacular name: Dan sinki

Fructification: June-July.

Voucher specimen: Nuwakot, Kakani, 2400 m, July 28, 2008, S. Singh 455 (TUCH). Terrestrial, on shady and wet rocks and slopes of forest, rare

Uses: A decoction of plant, about 4 teaspoons twice a day is given for gastric trouble. Juice of the rhizome, about 4 teaspoon three times a day, is given in case of fever. It is also used to treat indigestion.

Distribution: Nepal (WCE, 100-2300 m), China, India, Sri Lanka, Malaya Peninsula, Malaysian islands, Africa, Mauritius.

Note: This is rare fern of Nepal.

\section{Adiantum philippense L.}

Synonyms: Adiantum lunulatum

Local vernacular name: Kani uneu

Fructification: June-July

Specimen Examined: Nuwakot, Kakani, 2400 m, July 10, 2008, S. Singh 452 (TUCH). Terrestrial on stones and rock crevices, wall and sandy slopes of shady moist places, occasion.

Uses: Juice of the rhizome is given in case of fever, dysentery and glandular swelling.

Distribution: Nepal (WCE, 60-2400 m), India, Sri Lanka, Myanmar.

\section{Adiantum raddianum C. Presl (Fig. 2)}

Synonyms: Adiantum cuneipinnulum

Fructification: April-July

Specimen Examined: Kathmandu, Sundarijal, 1700 m, July 23, 2008, S. Singh 461 (TUCH). Terrestrial on shady moist forest slopes and on stone crevices, rare.

Uses: Used as tonic, resolvent, expectorant, diuretic, emmenagogue, astringent, emetic and in scorpion sting (Ambasta 1986, Jain 1991).

Distribution: Nepal (E. 850 -2000 m), Afghanistan, Northeast Himalayas, West China, America.

Note: This species was previously recorded only from E Nepal, Mechi zone, Taplejung district, Sinwa-Chhirwa, along the main trekking path to Kanchunjunga basecamp, c. 15 min. walk from Sinwa, on the foot of big rock, at the altitude 850m, Thapa, 27 Jul. 001, T (KATH) (Thapa 2002). This is rare in Nepal and in the present specimen it is reported for the first time from central Nepal. 


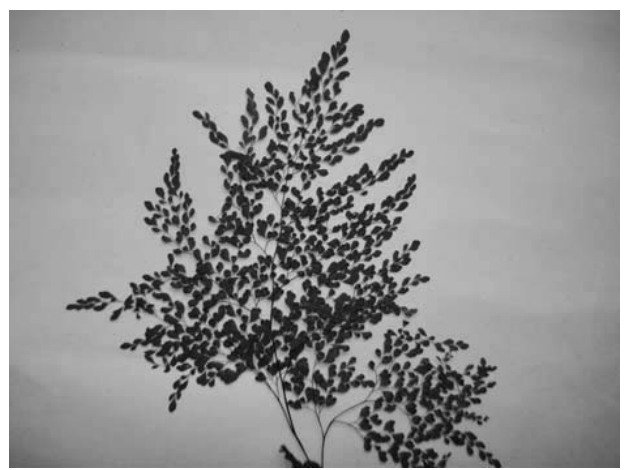

Habit

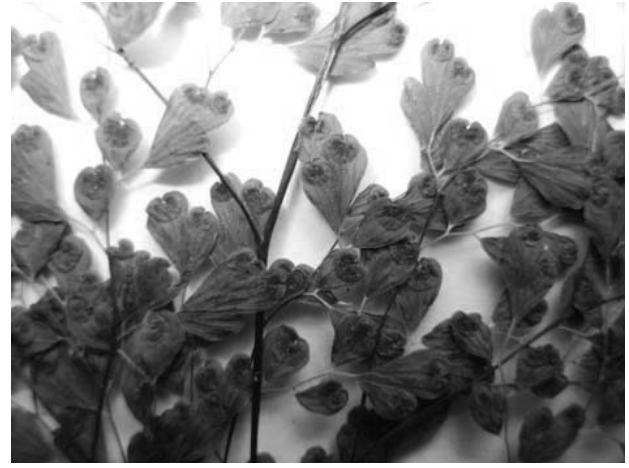

Fronds showing Sori

Figure 2. Adiantum raddianum C. Presl.

Out of four species, Adiantum raddianum is a new record to this area. This is an adventives species from $\mathrm{C}$ and $\mathrm{S}$ America. This is widely popular in cultivation. Among the remaining species Adiantum caudatum and Adiantum philippense are rare in Nepal, whereas, Adiantum capillus-veneris is commonly distributed.

\section{ACKNOWLEDGEMENTS}

We are grateful to Prof. Dr. Krishna Kumar Shrestha, former Head of the Central Department of Botany and the National Herbarium and Plant Laboratories (KATH) for providing necessary facilities to undertake the research. We also want to express our sincere thanks to $C$. R. FraserJenkins for helping to confirm the identification of species. Thanks also go to the Department of National Park and Wildlife conservation and Warden Office of the Shivapuri National Park for providing permission to visit the field for collecting the specimens. One of the authors (SS) is thankful to the University Grants Commission (UGC) for providing financial support for this work.

\section{REFERENCES}

Ambasta, S.P.,1986. The Useful Plants of India. CSIR, New Delhi.

Beddome, R.H.,1883. Handbook to the ferns of British India Ceylon and the Malay Peninsula. Calcutta. Reprinted 1976, New Delhi.

Clarke, C.B.,1880. A Review of the ferns of northern India etc. Trans. Linn. Soc. (Lond.), Ser. 2, Bot., 1:425-619.

Fraser-Jenkins, C.R., 2008. Taxonomic revision of three hundred Indian subcontinental pteridophytes with a revised census-list. 1-685. Bishen Singh Mahendra Pal Singh Dehra Dun India.

Gurung, V.L.,1991. Ferns- the beauty of Nepalese flora. Kathmandu, Nepal.

Hope, C.W.,1899-1904. The Ferns of North-Western India. J. Bombay Nat. Hist. Soc.,12-14. Iwatsuki, K.,1975. Pteridophyta in flora of eastern Himalaya. Univ. Mus. Univ. Tokyo Bull., 8: 
166-205.

Iwatsuki, K.,1988. An enumeration of the pteridophytes of Nepal. The Himalayan plants (1). Univ. Mus. Univ. Tokyo Bull., 31:231-339.

Jain, S.K.,1991. Dictionary of Indian folk medicines and ethnobotany. Deep Publ., New Delhi, India.

Malla, S.B., S.B. Rajbhandry, T.B. Shrestha, P.M. Adhikari, S.R. Adhikari and P.R. Shakya,1986. Flora of Kathmandu Valley. Bull. Dept. Med. Plants, Nepal, No. 11. Department of Medicinal plants, HMG Nepal, Kathmandu.

Thapa, N., 2002. Pteridophytes of Nepal. Ministry of Forests and Soil Conversation. Department of Plant Resources, National Herbarium and Plant Laboratories, Lalitpur, Nepal.

\section{AUTHORS' ADDRESS}

\section{Sabina Singh (Shrestha) ${ }^{1}$}

Padmakanya Multiple Campus, Tribhuvan University, Bagbazar Kathmandu (email: sabinasingh32@hotmail.com)

\section{Mohan Siwakoti ${ }^{2}$}

Central Department of Botany, Tribhuvan University, Kirtipur, Kathmandu 